Антошко Марина Олегівна

кандидат мистецтвознавства, доцент, доцент кафедри загального та спеціалізованого фортепіано Національної музичної академії

України імені П.І.Чайковського ORCID 0000-0002-4105-7519 antoshko.m@rambler.ru

\title{
РОЗВИТОК ФОРТЕПІАННОГО МИСТЕЦТВА У КИТАЇ
}

\begin{abstract}
Мета роботи присвячена проблемі розвитку фортепіанного мистецтва у Китаї. Методологія дослідження передбачає використання історичного та біографрічних методів у вивченні даної тематики. Наукова новизна статті полягає у дослідженні доцільності проблеми розвитку фортепіанного мистецтва у Китаї, вивчення історичних витоків даної проблематики. У роботі згадані історичні імена діячів, які безпосередньо вплинули на розвиток фортепіанного мистецтва у Китаї, завдяки яким були з'ясовані культурні традиції країн Сходу. Висновки: на основі вивчення проблеми, що стосується фортепіанного мистецтва у Китаї, виявили процеси розвитку його та самобутню культуру. Виокремити імена відомих педагогів та музикантів Китаю, які здійснили вплив на розвиток та становлення мистецтва країни. Виявити вплив філософії на мислення та розуміння фортепіанного мистецтва.
\end{abstract}

Ключові слова: фортепіанна музика Китаю, музичне мистецтво, культурні традиції, музичне виконавство.

Антошко Марина Олеговна, кандидат искусствоведения, доцент кафедры общего и специализированного фортепиано Национальной музыкальной академии Украины имени П.И.Чайковского Развитие фортепианного искусства в Китае

Цель работы посвящена изучению проблемы развития фортепианного искусства в Китае. Методология исследования предполагает использование исторического и биографических методов в изучении данной тематики. Научная новизна статьи заключается в исследовании целесообразности проблемы развития фортепианного искусства в Китае, изучение исторических истоков данной проблематике. Впервые были выделены исторические имена деятелей, которые непосредственно повлияли на развитие фортепианного искусства в Китае, благодаря которым были выяснены культурные традиции стран Востока. Выводы: на основе изучения проблемы, касающейся фортепианного искусства в Китае, обнаружили процессы развития его и самобытную культуру. Выделить имена известных педагогов и музыкантов Китая, которые оказали влияние на развитие и становление искусства страны. Выявить влияние фрилософии на мышление и понимание фрортепианного искусства.

Ключевые слова: фрортепианная музыка Китая, музыкальное искусство, культурные традиции, музыкальное исполнительство.

Antoshko Marina, Candidate of Arts, Associate Professor of the Department of General and Specialized Piano of the National Music Academy of Ukraine named after P. Tchaikovsky

The development of piano art in China

The purpose of the article is to study the problem of the development of piano art in China. The methodology of the research is to use historical and biographical methods in the study of this topic. The scientific novelty of the article is to study the expediency of the problem of the development of piano art in China, studying the historical origins of this problem. For the first time, the historical names of the figures who directly influenced the development of piano art in China, which clarified the cultural traditions of the East. Conclusions. On the basis of the study of the problem concerning piano art in China, they discovered the processes of development of his and distinctive culture. Identify the names of the well-known teachers and musicians in China that have influenced the development and development of the country's art. Identify the influence of philosophy on thinking and understanding of piano art. The system of thinking of modern piano art is based on ancient Chinese philosophy. The musical culture of China is in constant search for the nature of sound, timbre palette, form, combining national motives. Through the combination of national features, country philosophy, religious tendencies, elements of vocal and instrumental folklore, theater and composition and piano culture, China's musical piano culture has become well-known in the world. The technique of piano playing is based on strict classical methods and national consciousness, which have been etched in the centuries. It was the Vietnamese school and the Yuege educational system that formed the basis for the development of Chinese musical culture. Thus, a great influence on the development of music education was made by: Shen Shingong - one of the first piano teachers, Jeng Jimin, who founded the music school in Shanghai, Lee Shutong - taught singing and piano at the Shanghai Women's School and Nanjing Higher School. An important role in the formation of piano art was played by Din Shande, who combined Western and Eastern motifs on the example of his works. These issues are interesting and require further study by scientists.

Key words: the piano music of China, musical art, cultural traditions, musical performance.

Актуальність теми дослідження. Проблема вивчення фортепіанного мистецтва у Китаї є цікавою та актуальною, адже зумовила повернення до історичних витоків, які безпосередньо вплинули на музичну культуру країни. Фортепіанне мистецтво відігравало значну роль у культурі країн Сходу, зокрема Китаї. Говорячи про китайську культуру, слід зазначити, що спів, музика і танок тісно пов'язані між собою. Розуміння мистецтва музики, зокрема фортепіанного мистецтва проходить крізь всю китайську фрілософрію та історію.

() Антошко М. О., 2020 
Аналіз досліджень: Питання історичних витоків Китаю завжди цікавило науковців, серед яких слід виокремити - Ю. В. Тавровського, Г. О. Шнеерсона, В.С. Виноградова. Серед китайських вчених слід зазначити С.Судзуки, який займався дослідженням культури Китаю та більш сучасні роботи, серед яких вирізняються праці Лю Ляня, Сюй Чжея та інші. Серед представників першої китайської фрортепіанної школи виокремлюємо: Дін Шан-де, Лі Сянь-мін, Лі Цуй-чжень, Фань Цзи-сень та інших. Отже, ми бачимо, що питання фортепіанного мистецтва у Китаї $є$ ще досі недостатньо висвітленим і потребує подальшого вивчення.

Метою роботи є вивчення проблеми музичної культури Китаю, зокрема теми фортепіанного мистецтва, яка є цікавою своєю історією, що уходить корінням в давнину.

Виклад основного матеріалу. Китайська фортепіанна музика, як і музичне мистецтво в цілому, - була відображенням східної фрілософії. Звернувшись до історії, слід сказати, що на процес фундації фортепіанного мистецтва у Китаї впливали як європейська музична традиція, так і китайська. Отже, період XX століття ознаменувався появою відомих європейських музикантів, які створили підґрунтя для розвитку фортепіанного мистецтва й освіти. Завдяки їх праці з'явилась когорта музикантів, - представників першої китайської фортепіанної школи. Серед них виокремлюємо: Дін Шан-де, Лі Сянь-мін, Лі Цуй-чжень, Фань Цзи-сень та інші. В свою чергу, китайські педагоги притримувались своїх національних традицій, зокрема китайської фрілософії та естетики, яку ставили виразником музичної думки. Китайські погляди націлені на вираз духовності, що отримало назву - «гра іцзін». Художні образи, що притаманні цій манері, мали своє відображення у живописі, літературі, каліграфії, танцях тощо. Концепція «іцзин» стверджує, що краса наповнення художнього твору може бути як реальною (об'єктивною), так і проявляться у образному прояві (суб'єктивною). У музичному мистецтві - ця манера виступає об'єднуючою ланкою між втіленням та внутрішнім проявом духовності виконавця. Згідно китайської ідеології та фрілософії, виконавці мали відкривати всю багатогранність та красу у музиці, красу природи за рахунок свободи, тонкості музичного виконавства. Техніка виконавства у Китаї побудована на розвитку асоціативного ряду, отже, на перше місце ставилось не розвиток технічних навичок, а саме асоціативних проявів за рахунок багатого образного строю. Адже китайська фрілософія підтримує ідею «гармонії світу», тому популярністю користуються теми природи та краси. Згідно фрілософії конфуціанства, людина має приборкувати свої емоції, як внутрішньо, так і зовнішньо. Це яскраво знайшло свій прояв у мистецтві музики, танцю, театрі та живопису. Згідно цим правилам, у мистецтві ці канони дотримані. Зокрема, на картинах, в живописі «гохуа» мімічні жести стримані, а картини мають переважно спокійний характер. У музиці також ці правила мали місце, адже зайві рухи тілом вважались недоцільними при грі на фортепіано. Все фортепіанне мистецтво побудовано на асоціативних моментах, адже ставлять головним завданням передати слухачам духовну сторону музики. В класичному мистецтві Китаю така внутрішня позиція вважається проявом енергії «ці», що за законами східної фрілософії ототожнює життєву силу, дихання та духовне начало. Саме музика допомагає людині знайти гармонію у своєму мисленні, привести душу до ладу, вважають китайці. Основною тенденцією у вихованні фортепіанною культурою країн Сходу є звернення до національних традицій. Фольклор був тим фундаментом, на який спирались музикознавці та композитори. Музичне мистецтво відображало зв'язок з древніми музичними інструментами (гітара піба, скрипка хуцінь, бамбуковая фрлейта ді, барабани, гонги, дзвіночки) та народною піснею. Серед дослідників, що займались проблемою китайського фольклору та композиції слід назвати імена: Ю Чі Хонга, Тун Дао Ціна, Сун Мін Чу, Ван Гуанчі, Ян Інь Лю, Ю Куан Інга. Проблеми впливу народних тенденцій на оркестрову та фортепіанну музику піднімає піаніст та музикознавець Чжоу Лонг, а також Р. Клеменс та Л. Пісано. Згідно китайської фрілософії, фортепіанне мистецтво пов'язано з категорією «Чі» (життєва енергія), яка за твердженнями конфуціанства є основою людини. Китайська культура поєднує поняття «Чі» із «Юйнь» (душа), які здійснюють вплив на мистецтво гри. Отже, такі твори як : Лі Ін Хая «Пісня Чжен і Сяо», Чу Ван Хуа «Музика заходу» яскраво представляють ці східні ідеї тощо. Досягненням китайських композиторів вважається підручник «Ввідний курс гри на музичному інструменті цінь», де подаються відомості про музичні характеристики інструмента цінь та китайської дудки. Своєрідність музичних творів підкріплена використанням діалекту «ханьюй», адже фортепіанні п'єси побудовані на ритмах та мелодіях народу хань. На звукову палітру впливають тембральні навантаження. Поряд з моментами пісенного та танцювального фольклору, фрілософія китайської музики яскраво знаходить своє відображення в творах Дін Шан Де, Ван Лі Шань, Чу Вей, Гуо Чі Ходг, Чу Ван Хуа тощо. Слід зазначити, що саме система пентатоніки зародилась в древніх пластах китайського фольклору. Система мислення сучасного фортепіанного мистецтва побудована на древній філософії Китаю. Проблема сучасного мистецтва Китаю XX століття поділяється на три основних напрямки: шанхайське, американське та пекінське. Відомим композитором, автором твору для скрипки з фортепіано «Нічний пейзаж» (1947) став Сан Тун з Шанхаю. Його робота насичена своєрідним колоритом, дисонансами в акордово-поліфонічній фактурі. Типовим $€$ використання композитором народних елементів, що простежуються у використанні пентатоніки. Ще одним відомим композитором, теоретиком у Китаю був Чен Міньчжі, який приділив багато часу розробкам питання поліфонії. Серед його робіт: «Вчення о поліфонічних елементах в китайській народній музиці», «О 24-х прелюдіях і фугах Шостаковича», він є автором ракохідної фуги та додекафонної прелюдії і фуги, вісьми п'єс для фортепіано, використавши додекафонну техніку на 
поліфонічній основі [4, 244]. Яскравим композитором цієї доби був Хо Шінтьєн, який створив такі шедеври китайського мистецтва: «Тональні приклади», «Чотири сна», «Телепатія», «Дві земні гілки», «Звуки природи», «Фонізм», «Приклад звукової сюїти», «Барабан сестри», «Голос з неба» тощо. Композитор використовує різні тембри національних інструментів, а також метод поступового зростання темпу ударних. Цей прийом має давнє коріння, адже використовувався ще під час буддійської служби, коли монахи під час читання текстів поступово збільшували темп, при цьому використавши гру на музичних інструментах. Відомим музикантом був Ян Лічінь, який став автором книги «Олів'є Мессіан» та проаналізував техніку музичного язика. Відомим китайським композитором був Тан Дун, який став відомим за рахунок написаних ним опер, симфоній, концертів для віолончелі, фрортепіано, гітари, а також інструментальної музики. Парадоксально авангардною є його музика, особливо його твір «Опера привидів» для струнного квартету і піпи. Твір цікавий тим, що у творі відтворюються шуми води, каміння, паперу та металу, на слова композитора. Митець використовує нехарактерні для музики Заходу тембральні окраси, а також користується китайським народним інструментарієм, зі співом чоловіка жіночим голосом, зі сценічними принципами композиції. Камерна сфера починає свій розвиток за рахунок таких творів, як: Вісім п'єс у стилі Хунань для фрортепіано, струнний квартет «Фен Я Сун», «Ці осіннього вітру» для голосу та шістьох інструментів, «Два вірші Лі Бо» для голосу та струнного квартету. Цікавим для слухачів є його твір «Оркестрова музика з інтермецо на варійовані тембри» для голосу, бас кларнету, контрабасу й симфонічного оркестру. Відомим автором симфоній був Ван Сілін, який продовжив у своїх творах традиції трагічного симфонізму Д. Шостаковича. До прикладів китайської національної культури, тембрового насичення звертається у своїх творах Ку Венті. Його відомими творами є «Висячі похорони на прямовисній скелі» для двох фрортепіано й оркестру, «Тернистий шлях до Шу», струнні квартети - «Балада річки», «Народні ігри», концерт для фрлейти з бамбуку «Гора туги й порожнечі». Цікавим $є$ партитура для інструментального ансамблю «Народне свято». У творі Лю Чаньюань «Зітхання», композитор використовує 12-ти тонову систему. Цікавими є такі твори композитора: «Ода» для саксофону, фортепіано та ударних, Тріо для фрлейти, віолончелі та фрортепіано, Симфонія для синтезатору, ударних та струнного оркестру, «Жарт» для оркестру тощо. Саме тут композитор проявляє своє внутрішнє почуття музичного колориту, поєднуючи східні мотиви з деталізацією звуків, притаманній західній музичній культурі. Отже, китайська композиторська школа побудована на естетичній єдності. Музична культура Китаю знаходиться у постійному пошуку характеру звуку, тембрової палітри, форми, поєднуючи в собі національні мотиви.

Завдяки поєднанню національних рис, фрілософії країни, релігійних тенденцій, елементів вокального та інструментального фольклору, театру та сфрери композиції та фрортепіанної культури, музична фортепіанна культура Китаю стала відомою в світі. Методика фортепіанної гри побудована на суворих класичних методах та національній свідомості, які викарбовувались віками. Відомо, що одним з перших, хто пропагантував фрортепіанне мистецтво був італієць Маттео Річчі. Саме він грав на клавесині або клавікорді. Пізніше, у XVIII столітті поширенням фрортепіанної культури займався орден єзуїтів. Відомими іменами просвітників стали Жозеф Марі Аміо та Жан Жозеф де Граммон. Отже, відкриття християнських церков у Китаї сприяли розвитку фортепіанної культури. Церковні хори співали під акомпанемент фрортепіано, а в деяких школах навчали гри на музичних інструментах, зокрема й на фортепіано. Почалось відкриття шкіл у Ханчжоу, Нінбо, Пекіні, Шанхаї. Відмінно від європейських традицій, де фортепіанне мистецтво біло світським, у Китаї ця культура мала суто релігійний характер. Отже, й репертуар носив релегійні елементи. Основателем педагогіки у Китаї вважається Семюель Робінс Броун (1810-1880), який заснував школу у Кантоні у 1839 році. Ця школа була як початковою, так і середньою. У 1842 році ця школа переїздить до Гонконгу. У школі також викладали музичне виховання. Пізніше, у 1880 році відкривається у Китаї коледж, заснований Юнгом Джоном Алленом. Цей виховний заклад був призначений для знатних людей. Навчання продовжувалось близько вісьми років та готувало кадрів для релігійних цілей. Серед предметів, які викладались були: букви, прості тектові вчення, фортепіано, граматика, англійська мова, математика, географія, мистецтво мовлення, основи науки, астрономія, піфагорійська теорія, тригонометрія, хімія, фрізика, інтегральні та диференціальні рівняння, мореплавство, мінералогія, стратегія управління тощо. Музика викладалась впродовж усіх років та виконувала виховну роль. Ні танців, ні співів виховання не передбачало. Також у школі не передбачалось виховання професіональних музикантів та педагогів. У 1892 році в Шанхаї почала працювати школа, заснована Лаурою Хейхуд, в якій навчання було направлено на світські елементи. Вивчались спів, гра на музичних інструментах, танці тощо. Ще однією музичною школою, заснованою у 1881 році у Шанхаї став мистецький заклад св. Марії. Отже, зростання шкіл свідчить про те, що їснував інтерес до мистецької освіти, зокрема до вивчення фрортепіано. Навчання носило не достатньо професійний рівень, адже першими вчителями музики були американські місіонери з доволі низьким рівнем освіти. Репертуар складався з пісень та псалмів, які виконували більш ознайомчу роль, а ні ж виховну. Твори класичного зразку почали з'являтись лише з появою гастролів європейських митців та педагогів. До Китаю з гастролями приїздили Ф. Шаляпін, Ф. Крейслер, І. Фрідман, А. Рубінштейн, С. Рахманінов. Це стало сприятливим моментом у формуванні смаків європейської класичної школи та потребу в освіченості населення. У XIX - XX століття відбувається розвиток фортепіанного мистецтва. Династія Цінь виступала за ідею поєднання західного та східного ми- 
стецтва для досягнення подальшого розвитку у фортепіанному вихованні. Це підготувало зміни у композиторській сфрері, театральній діяльності, інструментальній та камерно-вокальній музиці, освіті, фольклорній діяльності тощо. Починає використовуватись більш широкий спектр інструментарія. Зокрема, арфи, скрипки, віолончелі, окрім фортепіано. Освіта набуває більш розширенних меж, що виходять за рамки консервативних, класичних понять. Починає працювати школа «Сюетан», де використовувалась система «Юеге». Засновником школи став Кан Ювей у 1898 році, який спирався на філософське вчення конфуціанців у вихованні. Він поєднав у виховному процесі як точні науки - математику, фрізику, хімію, астрономію, так і мистецькі - мову та літературу, зокрема музику. Ця освітня система поєднувала як японські та китайські здобутки освітнього процесу, так і європейські зразки. Отже, це вказувало, що система освіти всебічно розвивалась, поєднуючи унікальність та плідність процесу, виховуючи гармонійно розвинуту особистість. Система виховання включала підбір репертуару, осягнення основ музичної теорії та інструментальної практики. Викладання включало ознайомлення з багатоголоссям оркестрових та хорових творів, адже для китайської культури більш характерним було виконання одноголосних творів. Цікавим та новим було й ознайомлення з формами композиції, які використовували європейські композитори. Це проникнення нових форм здійснило великий вплив у розвиток китайської освітньої системи. Саме Сюетанська школа та виховна система «Юеге» стали фундаментом для розвитку китайської музичної культури. Так, виникає потреба у підручниках та посібниках, які б відобразили систему «Юеге». У 1904 році з'являється підручник «Зібрання матеріалів зі співу для шкіл», автором якого став Шень Сіньгун. У 1913 році Міністерство освіти запровадило в китайську освіту «Устав вищих педагогічних навчальних закладів», згідно якого в освітні процеси були введені музичні предмети, а саме спів та теорія музики. Видатними особистостями китайської музичної культури став Сяо Юмей (1884-1940) - вчений, композитор, просвітитель, який став засновником ряда професійних навчальних закладів та ввів курс спеціального фортепіано. Завдяки йому почали працювати такі освітні заклади, серед яких: Пекінське жіноче музичне училище (1921), музичні курси на базі Пекінського університету (1923), факультет музичного мистецтва в складі Пекінського училища мистецтв (1923) . А у 1927 році була відкрита консерваторія в Шанхаї, яка стала осередком мистецького життя. Відомим також стала Токійська школа музики, де навчання було забезпечено методичною літературою та нотами. У школі було достатньо музичних інструментів, зокрема фортепіано та фрісгармонії. У вихованні фортепіанних навичок використовувались етюди К. Черні, сонатини М. Клементі й Ф. Кулау, вправи Ш. Ганона. Отже, великий вплив на розвиток музичної освіти здійснили: Шен Шінгун - один з перших педагогів фортепіано, Цзень Чжимінь, який був засновником музичної школи в Шанхаї, Лі Шутон - викладала спів та фрортепіано у жіночій школі Шанхаю та Нанкінському вищому педагогічному училищі. Поряд з метрами фрортепіанної педагогічної школи, навчались гри на інструменті Хуан Пінь у Парижі (викладач Наді Буланже), Ван Шуйшан та Лі Єньке в Америці, Ян Цунчжі у Франції. Ці фрактори здійснювали свій вплив на подальший розвиток та вдосконалення фортепіанного мистецтва у Китаї. З'являються перші паростки композиторської школи, де поважне місце займають фортепіанні жанри. Відомим композитором у Китаї був Дінь Шанде (1911 - 1995), творець фрортепіанних програмних творів та ряду праць, в яких митець виказує роль національного мистецтва у культурі Китаю. Отже, в історію Китаю він увійшов як методист, композитор, теоретик, громадський діяч, педагог тощо. Під час свого навчання в консерваторії митець вивчав гру на китайському інструменті піпу, що нагадує європейську лютню, пізніше він почав вивчати фортепіано. Дінь Шанде викладав композицію на музичному факультеті Шанхайського університету, читав лекції з теорії музики та вів хоровий спів. Поряд з цим давав приватні уроки, гастролював, керував народними колективами. Таким чином, в своїх працях він вдало поєднує національні та європейські традиції музичного мистецтва. На манеру композиції його творів та світогляд здійснили вплив такі композитори, серед яких: А. Онеггер, О. Мессіан, А. Корто, Н. Галлон, Т. Обен. Поряд з ними й К. Дебюссі та М. Равель, з їх імпресіонізмом в музиці, тембровими окрасами. Відомими творами Дінь Шанде, де яскраво простежуються ці ідеї, відносяться цикл «Веселі канікули», сюїта «Подорож на весні», «Тема з варіаціями на тему китайської народної пісні». Педагогічні ідеї майстра втілювались у яскравості звукових навантажень та конструктивності викладу, що було запозичено з методик викладання європейських шкіл. Будучи викладачем Шанхайської консерваторії, він виховав цілу плеяду учнів - піаністів, композиторів, теоретиків та педагогів (Чжу Гоньї, Чжоу Гуанжень, Чень Мінчжі, Ло Чжунжун, Ші Юнкан, Ху Дентяо, Ло Чжуан, Чень Ган, Ван Сілінь, Ван Лао, Чжао Сяошен, Сюй Шуя тощо). Свої педагогічні ідеї він втілив у своїх підручниках та статтях: «Контрапункт строгого стилю» (1952), «Подвійний контрапункт» (1954), «Нариси 3 техніки фуги» (1957), «Дослідження прийомів композиції» (1987). Він піднімав питання етичних цінностей, національну проблематику, питання народного фольклору, які знаходили своє втілення в композиціях автора. Його спадщина нараховує близько 36 опусів, до яких увійшли твори фрортепіанні, камерні, вокальні, симфонічні та хорові. Характерними рисами творів Дінь Шанде є застосування пентатоніки, що відображає національний дух творів. Європейські традиції проявляються у автора крізь призму імпресіоністських тенденцій, що притаманні творам композитора. Традиції неокласицизму втілені у трактуванні форми, яка $€$ конструктивною. В творах композитора проявляються й поліфонічні тенденції. Його композиції поєднують синтез як західного, так і східного колоритів, особливо в фортепіанній 
творчості. Саме він поставив фрортепіано на європейський рівень, що увійшов в китайську музичну культуру, тим самим вивівши свій індивідуальний погляд та стиль на культуру Китаю.

Висновки. Система мислення сучасного фортепіанного мистецтва побудована на древній фрілософії Китаю. Музична культура Китаю знаходиться у постійному пошуку характеру звуку, тембрової палітри, форми, поєднуючи в собі національні мотиви. Завдяки поєднанню національних рис, фрілософрії країни, релігійних тенденцій, елементів вокального та інструментального фольклору, театру та сфрери композиції та фортепіанної культури, музична фортепіанна культура Китаю стала відомою в світі. Методика фортепіанної гри побудована на суворих класичних методах та національній свідомості, які викарбовувались віками. Саме Сюетанська школа та виховна система «Юеге» стали фрундаментом для розвитку китайської музичної культури. Отже, великий вплив на розвиток музичної освіти здійснили: Шен Шінгун - один з перших педагогів фрортепіано, Цзень Чжимінь, який був засновником музичної школи в Шанхаї, Лі Шутон - викладала спів та фортепіано у жіночій школі Шанхаю та Нанкінському вищому педагогічному училищі. Велику роль у становленні фоортепіанного мистецтва здійснив Дінь Шанде, який поєднав західні та східні мотиви на прикладі своїх творів. Дана проблематика є цікавою та потребує подальшого вивчення у науковців.

\section{תimepamypa}

1. Buchkovskaya O.Yu. (2015). Dialogue as the determinant of intercultural interaction. Extended abstract of the candidate's thesis. Kyiv: National acad.kers of culture and arts [in Ukrainian].

2. Kravtsova M.E. (2003). The History of Chinese Culture. Study aid for universities in the specialty "Culturology". St. Petersburg: Lan [in Russian].

3. Mykhailychenko O.V. (1997). Education and Training in Japan and China: Historical and Theoretical Aspect / International Institute of Humanization and Education Development. Sumy: Science [in Ukrainian].

4. Tarakanov M.E. (2003). Man and Phonosphere. Memories Saty Materials of the conference "The Phonosfera - Man - the Community". Moscow: St. Petersburg [in Russian].

5. U Iphan. (2012). Methodology of preparing future music teachers of Ukraine and China for work in conditions of the multicultural environment: Extended abstract of candidate's thesis. Kyiv: National ped.un. M.P. Drahomanov [in Ukrainian].

6. Chay Penchen. Formation of the artistic and stylistic competence of the future music teacher of Ukraine and China: Extended abstract of candidate's thesis. Kyiv: National ped.un. M.P. Drahomanov [in Ukrainian].

7. Yu Fey. (2014). Methodical principles of the preparation of future music teachers for teaching practice in higher educational establishments of China and Ukraine: Extended abstract of candidate's thesis. Kyiv: National ped.un. M.P. Drahomanov [in Ukrainian].

\section{References}

1. Бучковська О.Ю. Діалог як детермінанта міжкультурної взаємодії : автореф. дис.:Нац. акад.кер.кадрів культури і мистецтв. Київ.2015. 20с.

2. Кравцова М.Е.История культуры Китая.Учебное пособие для вузов по специальности «Культурология». СПб.:Лань, 2003.415с.

3. Михайличенко О.В. Освіта та виховання в Японії та Китаї: Історико-теоретичний аспект / Міжнародний ін.-т гуманізації та розвитку освіти. Суми: Наука, 1997. 122с.

4. Тараканов М.Е. Человек и Фоносфрера. Воспоминания. Сатьи. Материалы конференции «Фоносфрера - человек - сообщество». М.:СПб. 2003.300с.

5. У Іфан. Методика підготовки майбутніх учителів музики України і Китаю до роботи в умовах полікультурного середовища: авторефр. дис.:Нац. пед.ун-т ім. М. П. Драгоманова. Київ. 2012. 21с.

6. Чай Пенчен. Формування художньо-стильової компетентності майбутнього вчителя музики України і Китаю: авторефр. дис.:Нац. пед.ун-т ім. М. П. Драгоманова. Київ. 2014. 21с.

7. Юй Фей. Методичні засади підготовки майбутніх учителів музики до педагогічної практики у вищих навчальних закладах Китаю та України: авторефр. дис.: Нац. пед.ун-т ім. М. П. Драгоманова. Київ. 2014. 20с. 